Article

\title{
Preparation of Coated Corrugated Box for Controlled-Release of Chlorine Dioxide and Its Application in Strawberry Preservation
}

\author{
Yuanyuan $\mathrm{Li}^{1}$, Dan Ren ${ }^{1,2}$ and Dan $\mathrm{Xu}{ }^{1,2, *(1)}$ \\ 1 College of Food Science, Southwest University, Chongqing 400700, China; 18671573995@163.com (Y.L.); \\ rendan0709@swu.edu.cn (D.R.) \\ 2 Food Storage and Logistics Research Center, Southwest University, Chongqing 400700, China \\ * Correspondence: xud@swu.edu.cn
}

Received: 20 February 2020; Accepted: 4 March 2020; Published: 6 March 2020

check for updates

\begin{abstract}
Chlorine dioxide $\left(\mathrm{ClO}_{2}\right)$ has received great attention as a nontoxic and efficient antimicrobial agent for the preservation of fresh fruits and vegetables. A novel two-layer coated corrugated box was developed to release gaseous $\mathrm{ClO}_{2}$ under the trigger of moisture in this study. The inner surface of the box was firstly coated with a mixture of polyvinyl alcohol- $\mathrm{NaClO}_{2}$-diatomite and then with chitosan acetic acid solution. Results showed that $\mathrm{ClO}_{2}$ was successfully released under high humidity due to the reaction of $\mathrm{NaClO}_{2}$, water vapor and acid. The concentration of released $\mathrm{ClO}_{2}$ increased with the increasing $\mathrm{NaClO}_{2}$ content in the coating, while the addition of diatomite stabilized and extended the release. To evaluate the preservation effect, strawberries were packed in the coated box and stored at room temperature. Compared with the control, the decay rate and weight loss of the strawberries packed in the coated box $\left(9 \mathrm{~g} / \mathrm{L} \mathrm{NaClO}_{2}\right)$ were reduced up to $21.88 \%$ and $6.84 \%$, respectively. The surface color, firmness and nutrients content were also better maintained. Therefore, this coated corrugated box with the capability to release $\mathrm{ClO}_{2}$ under the trigger of moisture has great potential to be applied as an antimicrobial packaging for fresh fruits and vegetables.
\end{abstract}

Keywords: chlorine dioxide; controlled-release; antimicrobial packaging; coating; corrugated box

\section{Introduction}

Fresh fruits and vegetables are susceptible to microbial infection due to their rich nutrient content, high moisture content and mechanical damages during harvest and transportation [1], which greatly shorten their shelf-life and cause huge economic loss. Current strategies to control microbial infections in fresh fruits and vegetables include cold storage and the application of antimicrobial agents. Nowadays, antimicrobial packaging which incorporates antimicrobial agents in the packaging materials is emerging as a safe and efficient method to extend the shelf-life of fresh produce.

According to the form of action, antimicrobial packaging can be divided into two types: direct contact and indirect contact [2]. When a packaging material is incorporated with a non-volatile antimicrobial agent, it needs close contact with the packaged food to effectively inhibit the growth of microorganisms on the surface. However, for fresh fruits and vegetables with large specific surface areas and irregular shapes, which are mostly packaged in batches, it is unlikely to ensure their effective contact with the packaging material. Therefore, volatile or gaseous antimicrobial agents which are able to diffuse to the exposed surface of every packaged item, would be better options to be blended with packaging materials. However, the key is to control the release of antibacterial agents under appropriate conditions and to make the release stable and continuous.

Chlorine dioxide $\left(\mathrm{ClO}_{2}\right)$ is a broad-spectrum bactericide with strong oxidizing ability, which has been approved by US Food and Drug Administration (FDA) to be used as a disinfectant, sanitizer and 
sterilizant for fruits and vegetables at a residue level of $3 \mathrm{mg} / \mathrm{L}$ [3]. In vitro and inoculation studies have demonstrated that $\mathrm{ClO}_{2}$ could effectively inhibit the growth of Gram-negative and -positive bacteria [4,5], yeasts [6] and molds [7]. The mechanisms of inactivation include recognizing and reacting with the cell membranes to modify the conformation of proteins and lipids, penetrating the membranes to oxidize amino acids and proteins thus interrupting cell metabolism, inducing electrolyte leakage of cells, as well as inhibiting the mycelial growth and spore germination [8]. Moreover, $\mathrm{ClO}_{2}$ have been reported to interfere with biosynthesis of ethylene [9] and respiratory metabolism, which might be combined with the antibacterial effect to delay the ripening of postharvest produce. So far, $\mathrm{ClO}_{2}$ in various forms has applied to the preservation of logan [10], tomatoes [11], mangos [12], peppers [13], bamboo shoots [14], among others. The reduced microbial amount, improved storage quality and extended shelflife have been reported on these fruits and vegetables. In addition, $\mathrm{ClO}_{2}$ is capable to degrade toxin including pesticide residues through oxidation effect $[8,15]$, which further makes it an ideal candidate for fresh produce preservation.

However, gaseous $\mathrm{ClO}_{2}$ is explosive when its partial pressure is above 0.1 bar and is unstable when exposed to sunlight, making it hard to be stored or be transported. Therefore, self-releasing $\mathrm{ClO}_{2}$ systems have been developed to release gaseous $\mathrm{ClO}_{2}$ in individual packaging. For example, the crystalline form of $\mathrm{ClO}_{2}$ wrapped by permeable films has been incorporated into the packaging of strawberries [16] and blueberries [17], which sustainably released gaseous $\mathrm{ClO}_{2}$ and successfully reduced the decay incidence. $\mathrm{ClO}_{2}$ has also been encapsulated into $\alpha$-cyclodextrin, for which the releasing rate was controlled by temperature and relative humidity [18]. Systems for on-site generation of $\mathrm{ClO}_{2}$ under external triggers have also been developed, which generally involve the reaction between a precursor and one or several activators. The most commonly used precursor is sodium chlorite $\left(\mathrm{NaClO}_{2}\right)$, which reacts with acid and water molecules to produce $\mathrm{ClO}_{2} \cdot \mathrm{NaClO}_{2}$ and acid are usually incorporated in two different compartments and then are assembled together to allow the in situ release of $\mathrm{ClO}_{2}$ under high humidity, which is induced by the diffusion and mixing of $\mathrm{ClO}_{2}{ }^{-}$and $\mathrm{H}^{+}$[19-21].

This study is aiming to develop a novel antimicrobial corrugated cardboard box with the capability to release gaseous $\mathrm{ClO}_{2}$ under the trigger of moisture. Corrugated boxes or trays are widely used as packaging of fruits and vegetable for storing, transportation and display, due to their advantages such as lightweight, low cost, sustainability, suitable permeability, and good cushioning properties. Herein, a two-layer polymer coating composed of polyvinyl alcohol (PVA) containing $\mathrm{NaClO}_{2}$ and chitosan dissolved in $1 \%(\mathrm{w} / \mathrm{v})$ acetic acid has been applied on the inner-surface of corrugated box, in order to in-situ release gaseous $\mathrm{ClO}_{2}$ under the trigger of $\mathrm{CO}_{2}$ and water vapor generated by the respiration and transpiration effect of fresh fruits and vegetables. The physical properties and the releasing behavior of $\mathrm{ClO}_{2}$ of the coated corrugated box were investigated. Moreover, the coated box was used as packaging of fresh strawberries to evaluate its preservation effect.

\section{Materials and Methods}

\subsection{Materials}

PVA (degree of polymerization, 1700, alcoholysis degree, $99(\mathrm{~mol} / \mathrm{mol}) \%$ ) and diatomite (chemical pure) was purchased from Chron Chemicals Co., Ltd (Chengdu, China). $\mathrm{NaClO}_{2}$ (80\% purity) was purchased from Aladdin biochemical Polytron Technologies Inc. (Shanghai, China). All other chemicals used were of analytical grade. T4 aircraft boxes $(250 \mathrm{~mm} \times 200 \mathrm{~mm} \times 70 \mathrm{~mm})$ made of $\mathrm{E}$ flute corrugated cardboards with a thickness of $1.6 \mathrm{~mm}$ were supplied by Tuchang Packaging Co., Ltd (Xuzhou, China). Strawberries were obtained from a local greenhouse in Chongqing, China.

\subsection{Coating on Corrugated Boxes}

PVA (36 g) was dissolved in $910 \mathrm{~mL} \mathrm{30 \%}(v / v)$ ethanol aqueous solution followed by stirring at $85^{\circ} \mathrm{C}$ for $2 \mathrm{~h}$. Diatomite (3.6 g) and different amount of $\mathrm{NaClO}_{2}$ were dispersed in $90 \mathrm{~mL}$ deionized (DI) water and were then mixed with the prepared PVA solution to obtain mixtures of PVA-diatomite- $\mathrm{NaClO}_{2}$. 
The final concentrations of $\mathrm{NaClO}_{2}$ in the mixtures were 3, 6 , and $9 \mathrm{~g} / \mathrm{L}$, respectively. Chitosan solution with a concentration of $0.75 \mathrm{~g} / \mathrm{L}$ was prepared by dissolving chitosan flakes in $1 \%(\mathrm{w} / \mathrm{v})$ acetic acid aqueous solution.

To prepare $\mathrm{ClO}_{2}$ controlled-release corrugated boxes, the inner surface of corrugated boxes was successively coated by PVA-diatomite- $\mathrm{NaClO}_{2}$ mixture and chitosan solution. Firstly, $100 \mathrm{~mL}$ PVA-diatomite- $\mathrm{NaClO}_{2}$ mixture was evenly brushed on the inner surface of one corrugated box with an inner surface area of $1630 \mathrm{~cm}^{2}$, which was dried at room temperature. Secondly, $0.75 \mathrm{~g} / \mathrm{L}$ chitosan solution was sprayed onto the PVA-diatomite- $\mathrm{NaClO}_{2}$ layer of the corrugated boxes for three times, $30 \mathrm{~mL}$ each time. After dried at room temperature, the coated boxes were stored in an environment with relative humidity (RH) lower than $20 \%$ and temperature lower than $10^{\circ} \mathrm{C}$. The boxes coated by PVA-diatomite- $\mathrm{NaClO}_{2}$ mixture with the $\mathrm{NaClO}_{2}$ concentration of 3,6 and $9 \mathrm{~g} / \mathrm{L}$ were designated as $3 \mathrm{~g} / \mathrm{L} \mathrm{NaClO} 2,6 \mathrm{~g} / \mathrm{L} \mathrm{NaClO}$ and $9 \mathrm{~g} / \mathrm{L} \mathrm{NaClO}$, respectively, while boxes with no treatment were used as control. To investigate the effect of diatomite, corrugated boxes were coated by a mixture of PVA and $\mathrm{NaClO}_{2}$ with the $\mathrm{NaClO}_{2}$ concentration of $9 \mathrm{~g} / \mathrm{L}$ and chitosan solution successively, following the same procedure except no diatomite was added, which were designated as $9 \mathrm{~g} / \mathrm{L} \mathrm{NaClO}{ }_{2}$ (No diatomite).

\subsubsection{Physical Properties of the Coated Corrugated Cardboard and Box}

Corrugated cardboards cut from the coated corrugated box were placed in a climatic chamber with $90 \% \mathrm{RH}$ and a temperature of $20^{\circ} \mathrm{C}$ for $24 \mathrm{~h}$ prior to the testing of physical properties, except for the samples used for moisture content measurement.

The thickness of corrugated cardboard was measured by a PD-151 digital vernier caliper (Prokit's Industries Co., Ltd, Shenzhen, China).

The moisture content was measured according to the Chinese National Standard GB/T 462-2008. Sample with a size of $10 \mathrm{~cm} \times 10 \mathrm{~cm}$ was dried at $105 \pm 2{ }^{\circ} \mathrm{C}$ to a constant weight in an oven. It was immediately weighed after taking out, and was put in a climatic chamber with $90 \% \mathrm{RH}$ and a temperature of $20^{\circ} \mathrm{C}$ until it reached a constant weight. The moisture content of the cardboard was calculated using Equation (1).

$$
\text { Moisture content }(\%)=\left(m_{1}-m_{0}\right) / m_{0} \times 100
$$

where $m_{0}$ is the weight of the cardboard after drying, and $m_{1}$ is the weight of the cardboard after moisture absorption in the climatic chamber.

The puncture strength (PS) of corrugated cardboard was measured by an HD-510S digital cardboard puncture tester (Haida International Equipment Co., Ltd., Dongguan, China). The test was carried on samples with a size of $175 \mathrm{~mm} \times 175 \mathrm{~mm}$ according to the Chinese National Standard GB/T 2679.7-2005. The flat crush strength (FCS) and the edge crush strength (ECS) of corrugated cardboard were measured by an HD-513E compressive strength tester (Haida International Equipment Co., Ltd., Dongguan, China). The samples used for the FCS test were cut to circles with a diameter of $64 \mathrm{~mm}$, while those used for the ECS test were cut into rectangles with a size of $25 \mathrm{~mm} \times 100 \mathrm{~mm}$, respectively. The ECS and FCS tests were carried out in accordance with the Chinese National Standard GB/T 22874-2008 and GB/T 6546-1998, respectively.

The box compressive strength (BCS) of the corrugated box was measured by an HD-502-1000 carton pressure tester (Haida International Equipment Co., Ltd., Dongguan, China). The box to be tested was fixed by a guide plate in the middle of the lower pressure plate, which moved up at a speed of $12 \mathrm{~mm} / \mathrm{min}$. The maximum pressure applied on the box before it crushed was recorded as BCS.

\subsection{2. $\mathrm{ClO}_{2}$ Release Test}

The release rate of $\mathrm{ClO}_{2}$ from the corrugated cardboard was measured under $100 \% \mathrm{RH}$ and $0 \%$ $\mathrm{RH}$, respectively. In order to obtain an environment with $100 \% \mathrm{RH}, 200 \mathrm{~mL}$ deionized (DI) water was put in the bottom of a brown glass desiccator for $24 \mathrm{~h}$ before the test. Cardboard with a size of $20 \mathrm{~cm}$ 
$\times 20 \mathrm{~cm}$ was put on the porcelain plate with holes in the desiccator without contact with DI water. The desiccator was then air-tightly sealed by a greased lid. The concentration of $\mathrm{ClO}_{2}(\mathrm{mg} / \mathrm{L})$ in the desiccator was measured every $24 \mathrm{~h}$ by a $\mathrm{GC} 510 \mathrm{ClO}_{2}$ gas detector supplied by Chicheng Electric Co., Ltd. (Henan, China). After each measurement, the desiccator was open for 30 min until no $\mathrm{ClO}_{2}$ was detected, and the desiccator was sealed again. To measure the release rate of $\mathrm{ClO}_{2}$ under $0 \% \mathrm{RH}$, $200 \mathrm{~g}$ silica gel was put in the bottom of a desiccator for $24 \mathrm{~h}$ instead of $200 \mathrm{~mL}$ DI water prior to the placement of the cardboard. Before the coated cardboard was placed in, silica gel was removed to prevent $\mathrm{ClO}_{2}$ from being absorbed by silica gel. After each measurement, the tested cardboard was moved to another desiccator with $0 \% \mathrm{RH}$. Other procedures were the same as that of the test under $100 \% \mathrm{RH}$. The release efficiency of $\mathrm{ClO}_{2}$ from the corrugated cardboard was calculated using Equation (2) and expressed as a percentage:

$$
\text { Release efficiency }(\%)=W_{n} / W_{\text {total }} \times 100
$$

where $W_{n}$ is the accumulated release amount of $\mathrm{ClO}_{2}$ at day $\mathrm{n}$, which is a sum of daily release from day 0 to day $n$, and $W_{\text {total }}$ is the total amount of $\mathrm{ClO}_{2}$ that can be theoretically released from the tested corrugated cardboard based on the amount of $\mathrm{NaClO}_{2}$ coated on the cardboard.

\subsection{Application of Coated Corrugated Boxes in Strawberry Preservation}

Strawberries were transported from a local greenhouse into the lab on the day they were picked. Strawberries free from pathological and physical damage with the same maturity were disinfected with $0.02 \%(v / v) \mathrm{NaClO}_{2}$ aqueous solution and were dried under ambient condition. Strawberries were then randomly divided into four groups and were put into control, $3 \mathrm{~g} / \mathrm{L} \mathrm{NaClO}_{2}, 6 \mathrm{~g} / \mathrm{L} \mathrm{NaClO}$, $9 \mathrm{~g} / \mathrm{L} \mathrm{NaClO}{ }_{2}$ corrugated cardboard boxes, separately, with 16 fruits in each box. There were 12 boxes for each group and stored at $20 \pm 5{ }^{\circ} \mathrm{C}$ and $65 \% \pm 10 \% \mathrm{RH}$. Two boxes of each group were taken out randomly to evaluate the quality every day.

\subsection{Physico-chemical Quality Changes of Strawberries}

Fruits with visible mold growth and juice leakage were considered rotten. The decay rate was calculated as the percentage of accumulated rot on that day in the total number of strawberries in each group. Weight loss was expressed as a percentage of the initial weight. Each non-rotten fruit was weighed every day to calculated the weight loss. The surface color of strawberries was measured by an UltraScan PRO chromameter (Hunterlab, USA) at three sites of the surface of a strawberry avoiding rotting areas. Firmness was measured by a GY-4 fruit firmness tester (Top Instrument Co., Ltd., China). A 4-mm-diameter cylindrical probe was penetrated to a depth of $1 \mathrm{~mm}$ at three different points of the central zone of each fruit. At least three strawberries in each group without spoilage were used for testing.

Ascorbic acid content (AA) of strawberries was determined by $\mathrm{KIO}_{3}$ titration method [22]. Five fruits were homogenized and $10 \mathrm{~g}$ of the slurry was diluted using $2 \%(v / v) \mathrm{HCl}$ to $100 \mathrm{~mL}$, which was prepared in triplicate for each group. After standing for $10 \mathrm{~min}$ to extract, the mixture was filtered. Filtrate $(5 \mathrm{~mL}), 10 \mathrm{~g} / \mathrm{L} \mathrm{KI}$ solution $(0.5 \mathrm{~mL})$, ultrapure water $(2.5 \mathrm{~mL})$ and $5 \mathrm{~g} / \mathrm{L}$ starch solution $(2 \mathrm{~mL})$ were mixed and were titrated by $10 \mathrm{~g} / \mathrm{L} \mathrm{KIO}_{3}$ solution to a light blue until no color change within $30 \mathrm{~s}$. Mixture of $2 \%(v / v) \mathrm{HCl}(5 \mathrm{~mL}), 10 \mathrm{~g} / \mathrm{L} \mathrm{KI}$ solution $(0.5 \mathrm{~mL})$, ultrapure water $(2.5 \mathrm{~mL})$ and $5 \mathrm{~g} / \mathrm{L}$ starch solution $\left(2 \mathrm{~mL}\right.$ ) was titrated by $10 \mathrm{~g} / \mathrm{L} \mathrm{KIO}_{3}$ solution following the same procedure. AA content of fruit was calculated using Equation (3) and expressed as $\mathrm{mg} / 100 \mathrm{~g}$.

$$
\mathrm{AA}(\mathrm{mg} / 100 \mathrm{~g})=\frac{V \times\left(V_{1}-V_{0}\right) \times 0.088 \times 100}{V_{s} \times m}
$$

where $V$ is the total volume of strawberry slurry dilution $(\mathrm{mL}) ; V_{1}$ is the volume of $\mathrm{KIO}_{3}$ solution consumed to titrate the filtrate mixture $(\mathrm{mL}) ; V_{0}$ is volume of $\mathrm{KIO}_{3}$ solution consumed to titrate the 
mixture in which $5 \mathrm{~mL}$ filtrate was replaced by $5 \mathrm{~mL} 2 \%(v / v) \mathrm{HCl}(\mathrm{mL}) ; V_{s}$ is the volume of filtrate used to prepare the mixture to titrate $(\mathrm{mL}) ; m$ is the total mass of strawberry used to prepare the slurry (mg); 0.088 is the mass of AA that $1 \mathrm{~mL}$ of $1 \mathrm{mmol} / \mathrm{L} \mathrm{KIO}_{3}$ solution equal to $(\mathrm{mg})$.

Titratable acid content (TA) was determined using the $\mathrm{NaOH}$ titration method [23]. The strawberry slurry was prepared and $5 \mathrm{~g}$ of them was diluted to $100 \mathrm{~mL}$ using ultrapure water, which was prepared in triplicate for each group. After filtration, 2 drops of $1 \%(\mathrm{w} / \mathrm{v})$ phenolphthalein solution was added to $20 \mathrm{~mL}$ filtrate and was titrated by $0.1 \mathrm{~mol} / \mathrm{L} \mathrm{NaOH}$ solution to a light pink until no color change within $30 \mathrm{~s}$. TA content of fruit was calculated using Equation (4):

$$
\mathrm{TA}(\%)=\frac{V \times\left(V_{1}-V_{0}\right) \times f \times 100}{V_{s} \times m}
$$

where $V$ is the total volume of strawberry slurry dilution $(\mathrm{mL}) ; V_{1}$ is the volume of $\mathrm{NaOH}$ solution consumed to titrate the filtrate $(\mathrm{mL}) ; V_{0}$ is volume of $\mathrm{NaOH}$ solution consumed to titrate $20 \mathrm{~mL}$ ultrapure water $(\mathrm{mL}) ; V_{s}$ is the volume of filtrate used to titrate $(\mathrm{mL}) ; m$ is the total mass of strawberry used to prepare the slurry (mg); $f$ is the conversion factor of citric acid, which is $0.064 \mathrm{~g} / \mathrm{mmol}$.

The content of total soluble solids (TSS) was determined using an Abbe refractometer (2WAJ, Shanghai optical instrument five factory Co., Ltd., China) and was expressed in percentage.

\subsection{Statistical Analysis}

All the experiments were carried out in triplicate for each group and reported as means \pm standard errors. Data were statistically compared among groups by one-way analysis of variance (ANOVA). The significance of the mean value was determined by Duncan's multiple range testing with $p<0.05$.

\section{Results and Discussion}

\subsection{Characterization of Corrugated Cardboard and Box}

\subsubsection{Physical Properties of Corrugated Cardboard and Box}

The physical properties of the coated corrugated cardboard and box were measured and given in Table 1 . The thickness of cardboard increased about $0.05 \sim 0.06 \mathrm{~mm}$ after coating, while the moisture content increased by $3.4 \% \sim 3.5 \%$ due to the hydrophilic nature of PVA and chitosan. There was no significant difference in thickness and moisture content among $3 \mathrm{~g} / \mathrm{L} \mathrm{NaClO}, 6 \mathrm{~g} / \mathrm{L} \mathrm{NaClO} 2$ and $9 \mathrm{~g} / \mathrm{L}$ $\mathrm{NaClO}_{2}$ cardboard. However, the strength of cardboard was compromised by coating. According to the data shown in Table 1, PS, ECS, and FCS of all the coated cardboard decreased by about $3 \%, 28 \%$ and $20 \%$, respectively, compared with control. This might be attributed to the increased moisture content, which softened the cardboards [24]. As a result, BCS of the coated box, which mainly depended on ECS of the cardboard, was reduced by 35\% 38\% compared with that of control. However, the maximum number of stacking layers of the box packed with strawberries was calculated to be 50 according to the Chinese National Standard GB/T 6543-2008, which was still able to meet the practical needs.

Table 1. Thickness, moisture content and strength index of corrugated cardboard and box.

\begin{tabular}{ccccccc}
\hline Samples & $\begin{array}{c}\text { Thickness } \\
(\mathbf{m m})\end{array}$ & $\begin{array}{c}\text { Moisture } \\
\text { Content (\%) }\end{array}$ & $\begin{array}{c}\text { PS } \\
(\mathbf{J})\end{array}$ & $\begin{array}{c}\text { ECS } \\
(\mathbf{k N} / \mathbf{m})\end{array}$ & $\begin{array}{c}\text { FCS } \\
(\mathbf{k P a})\end{array}$ & $\begin{array}{c}\text { BCS } \\
(\mathbf{N})\end{array}$ \\
\hline $\mathrm{Control}$ & $1.59 \pm 0.02^{\mathrm{b}}$ & $12.69 \pm 0.36^{\mathrm{b}}$ & $4.75 \pm 0.03^{\mathrm{a}}$ & $1.25 \pm 0.12^{\mathrm{a}}$ & $65.40 \pm 3.44^{\mathrm{a}}$ & $587.22 \pm 59.97^{\mathrm{a}}$ \\
$3 \mathrm{~g} / \mathrm{L} \mathrm{NaClO}_{2}$ & $1.66 \pm 0.01^{\mathrm{a}}$ & $16.17 \pm 0.67^{\mathrm{a}}$ & $4.58 \pm 0.06^{\mathrm{b}}$ & $0.91 \pm 0.10^{\mathrm{b}}$ & $52.77 \pm 5.24^{\mathrm{b}}$ & $382.71 \pm 41.47^{\mathrm{b}}$ \\
$6 \mathrm{~g} / \mathrm{L} \mathrm{NaClO}_{2}$ & $1.66 \pm 0.02^{\mathrm{a}}$ & $16.11 \pm 0.53^{\mathrm{a}}$ & $4.57 \pm 0.05^{\mathrm{b}}$ & $0.90 \pm 0.08^{\mathrm{b}}$ & $53.41 \pm 3.09^{\mathrm{b}}$ & $366.93 \pm 21.90^{\mathrm{b}}$ \\
$9 \mathrm{~g} / \mathrm{L} \mathrm{NaClO}_{2}$ & $1.64 \pm 0.01^{\mathrm{a}}$ & $16.17 \pm 0.45^{\mathrm{a}}$ & $4.67 \pm 0.05^{\mathrm{b}}$ & $0.90 \pm 0.08^{\mathrm{b}}$ & $52.01 \pm 3.27^{\mathrm{b}}$ & $363.65 \pm 22.20^{\mathrm{b}}$ \\
\hline
\end{tabular}

Different lowercase superscripts $(a, b)$ within the same column indicate significant differences among the mean values of different groups $(P<0.05)$. 


\subsection{2. $\mathrm{ClO}_{2}$ Release Behavior from the Coated Corrugated Cardboard}

According to the reaction formula: $4 \mathrm{H}^{+}+5 \mathrm{ClO}_{2}^{-}=4 \mathrm{ClO}_{2}^{-} \uparrow+2 \mathrm{H}_{2} \mathrm{O}+\mathrm{Cl}^{-}, \mathrm{NaClO}_{2}$ embedded in the coating layer of corrugated cardboard has to contact with $\mathrm{H}^{+}$to produce gaseous $\mathrm{ClO}_{2}$ [19]. Therefore, a chitosan layer containing acetic acid has been coated on the top of the PVA-diatomite- $\mathrm{NaClO}_{2}$ layer to provide $\mathrm{H}^{+}$. Chitosan and PVA are hydrophilic polymers, which absorb water molecules and swell in a high humidity environment. Therefore, $\mathrm{H}^{+}$provided by acetic acid is able to move freely in the coatings and contact with $\mathrm{ClO}_{2}{ }^{-}$to produce gaseous $\mathrm{ClO}_{2}$. In order to verify this hypothesis, the releasing of $\mathrm{ClO}_{2}{ }^{-}$from coated cardboard was conducted at $100 \% \mathrm{RH}$ and $0 \% \mathrm{RH}$, respectively. As shown in Figure $1 \mathrm{a}, \mathrm{ClO}_{2}$ was detected in the desiccator containing $9 \mathrm{~g} / \mathrm{L}$ $\mathrm{NaClO}_{2}$ cardboard at $100 \% \mathrm{RH}$ since day 1, which reached the maximum concentration on day 3 and decreased gradually until day 14 . However, no $\mathrm{ClO}_{2}$ was detected to be released from $9 \mathrm{~g} / \mathrm{L} \mathrm{NaClO} 2$ cardboard at $0 \% \mathrm{RH}$ during the whole experiment. Bai et al. also found that $\mathrm{ClO}_{2}$ released at a very low rate from the label system under dry condition [20]. It clearly demonstrated that $\mathrm{ClO}_{2}$ could only be released when the cardboard was exposed to moisture. Therefore, the coated cardboard can be conveniently stored in a dry environment to avoid the loss of $\mathrm{ClO}_{2}$ prior to use. When applied as packaging of fruits and vegetables, a high humidity environment would be formed inside the box owing to the transpiration of produce, thus triggering the release of $\mathrm{ClO}_{2}$.
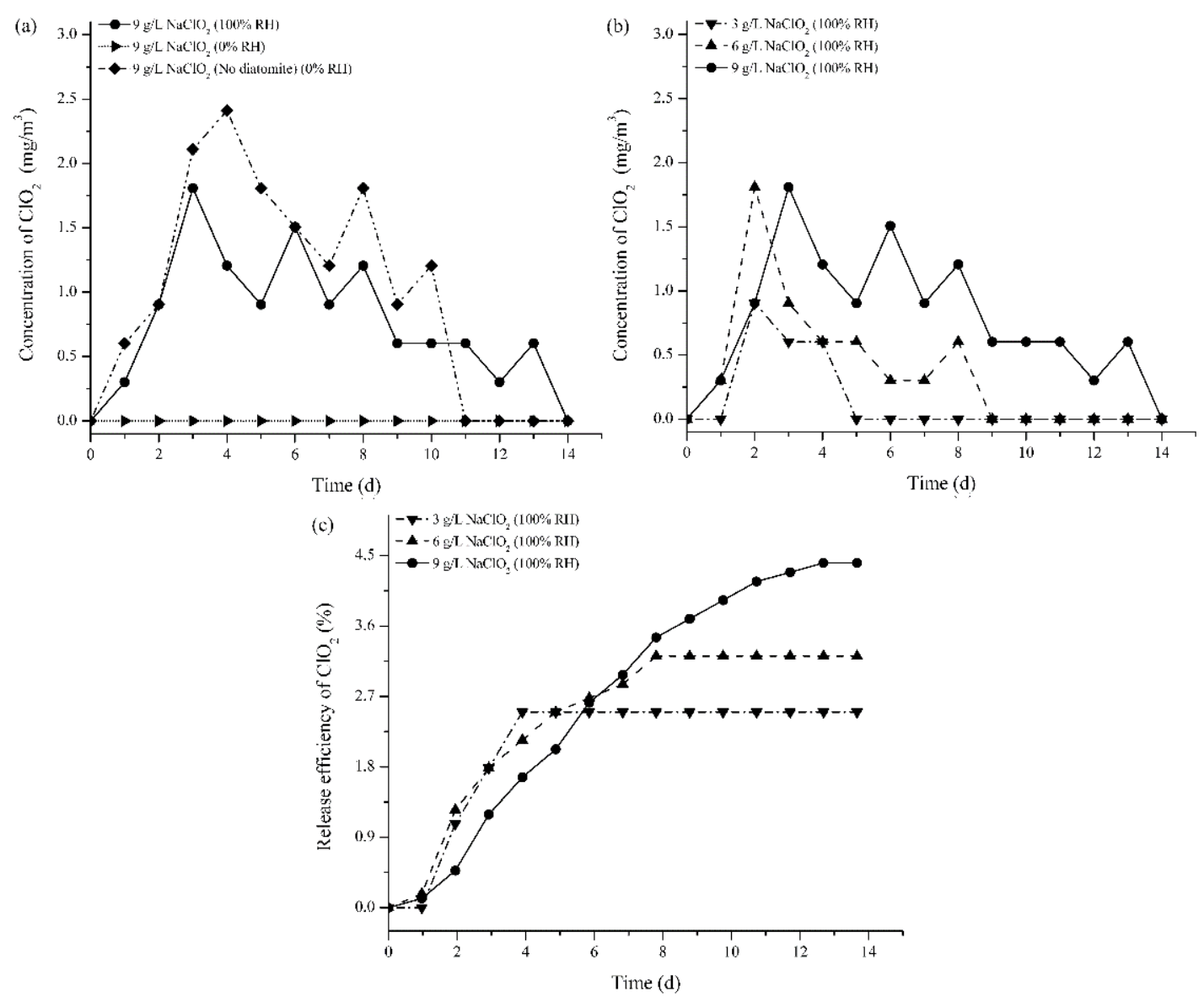

Figure 1. The release behaviors of $\mathrm{ClO}_{2}$ from the coated corrugated cardboards: (a) effects of relative humidity and diatomite on the release rate; (b) effects of $\mathrm{NaClO}_{2}$ concentration on the release rate; (c) effects of $\mathrm{NaClO}_{2}$ concentration on the release efficiency. 
The release behavior of $\mathrm{ClO}_{2}$ from the coated cardboard with and without diatomite $(9 \mathrm{~g} / \mathrm{L} \mathrm{NaClO}$ and $9 \mathrm{~g} / \mathrm{L} \mathrm{NaClO} 2$ (No diatomite)) at $100 \% \mathrm{RH}$ was also compared in Figure 1a. The results indicated that $9 \mathrm{~g} / \mathrm{L} \mathrm{NaClO} 2$ (No diatomite) showed a higher concentration of $\mathrm{ClO}_{2}$ since day 3 and reached the maximum value on day 4 . However, the $\mathrm{ClO}_{2}$ concentration of $9 \mathrm{~g} / \mathrm{L} \mathrm{NaClO}_{2}$ (No diatomite) decreased rapidly after day 4 and dropped to 0 on day 11 , while $9 \mathrm{~g} / \mathrm{L} \mathrm{NaClO}$ continued to release $\mathrm{ClO}_{2}$ until day 13. It demonstrated that the incorporation of diatomite together with $\mathrm{NaClO}_{2}$ in $\mathrm{PVA}$ coating stabilized and prolonged the release of $\mathrm{ClO}_{2}$. Diatomite is a siliceous sedimentary rock, well known by its finely porous structure and excellent adsorption property. Therefore, when it was mixed with $\mathrm{NaClO}_{2}$ in PVA, some ions of $\mathrm{ClO}_{2}{ }^{-}$might be absorbed into the porous channels of diatomite, thus slowing down their reaction with $\mathrm{H}^{+}$. The release process of $\mathrm{ClO}_{2}$ from the coated cardboard containing diatomite is schematically shown in Figure 2.

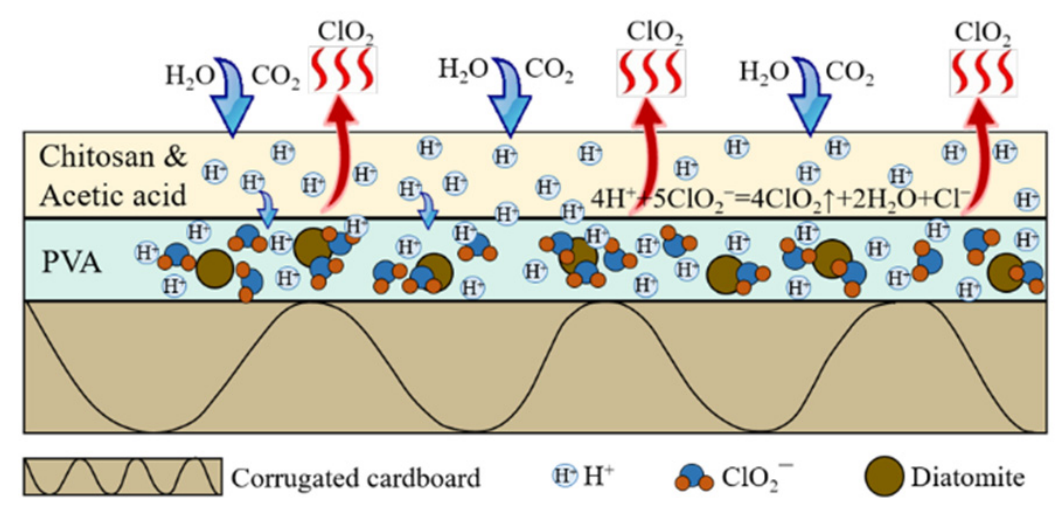

Figure 2. Schematic diagram of the release process of $\mathrm{ClO}_{2}$ from the coated corrugated cardboard.

The release behavior of $\mathrm{ClO}_{2}$ also depended on the $\mathrm{NaClO}_{2}$ concentration in the coated cardboard. As presented in Figure $1 \mathrm{~b}$, the increased $\mathrm{NaClO}_{2}$ concentration not only increased the concentration of $\mathrm{ClO}_{2}$ released in the desiccator but also extend the releasing time. $\mathrm{ClO}_{2}$ was not detected after day 4 for $3 \mathrm{~g} / \mathrm{L} \mathrm{NaClO}$, but it was continuously released from $6 \mathrm{~g} / \mathrm{L} \mathrm{NaClO}_{2}$ and $9 \mathrm{~g} / \mathrm{L} \mathrm{NaClO}{ }_{2}$ until day 9 and day 14, respectively. Figure $1 \mathrm{c}$ presented the increased release efficiency of $\mathrm{ClO}_{2}$ with time. The ultimate release efficiency of $9 \mathrm{~g} / \mathrm{L} \mathrm{NaClO}{ }_{2}$ was also higher compared to $6 \mathrm{~g} / \mathrm{L} \mathrm{NaClO}$ and $3 \mathrm{~g} / \mathrm{L}$ $\mathrm{NaClO}_{2}$. However, the release efficiency of all the coated cardboards was relatively low, which might be attributed to the loss during preparation and test.

\subsection{Effects of the Coated Corrugated Box on Strawberry Preservation}

\subsubsection{Decay Rate}

The decay rate of strawberry increased rapidly when stored at room temperature. As shown in Figure 3a, strawberries packed in control box started to decay on day 2, which showed a decay rate higher than $80 \%$ on day 5 . However, the decay rate of strawberries packed in $6 \mathrm{~g} / \mathrm{L} \mathrm{NaClO} 2$ and $9 \mathrm{~g} / \mathrm{L}$ $\mathrm{NaClO}_{2}$ boxes was two times lower compared to that packed in control on day 3 . The appearance of strawberries shown in Figure $3 \mathrm{~b}$ clearly revealed the mold growth was greatly inhibited when they were packed in $6 \mathrm{~g} / \mathrm{L} \mathrm{NaClO}{ }_{2}$ and $9 \mathrm{~g} / \mathrm{L} \mathrm{NaClO}_{2}$ boxes, which indicated the successful release of $\mathrm{ClO}_{2}$ in these boxes. In the boxes, water vapor and $\mathrm{CO}_{2}$ were able to be constantly produced by the active transpiration and respiration process of strawberries, which would be absorbed by the chitosan and PVA coatings on the cardboard and result in swelling of polymers chains and penetration of $\mathrm{H}^{+}$to react with $\mathrm{ClO}_{2}{ }^{-}$. As a result, gaseous $\mathrm{ClO}_{2}$ was constantly produced and released from the coating layer, which diffused to the surface of strawberries and killed the microorganisms via various mechanisms [25]. 

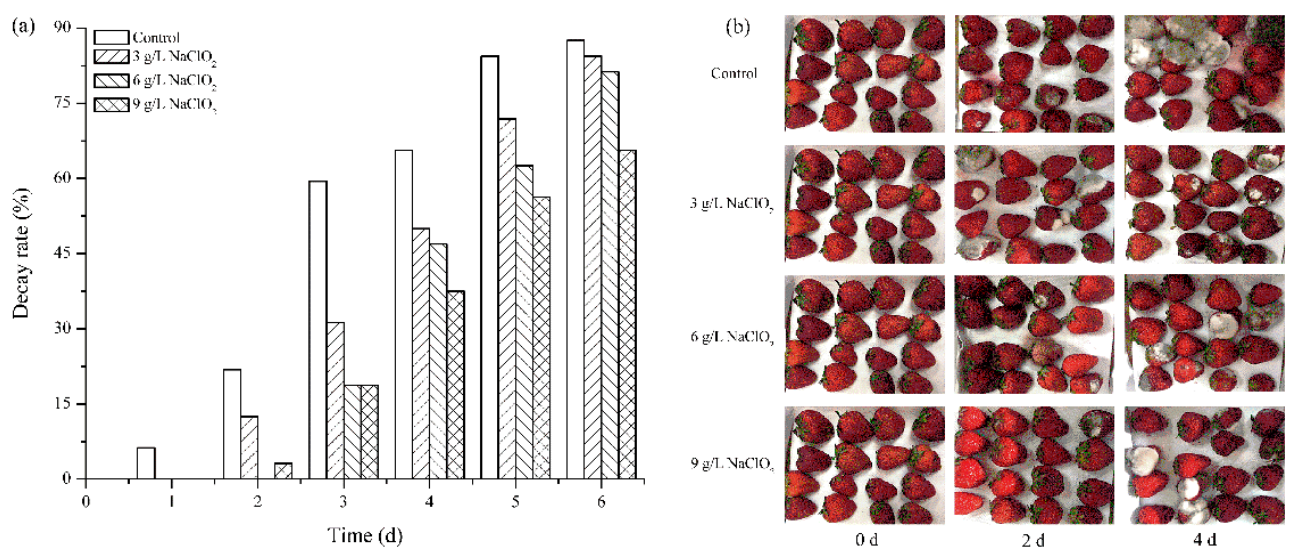

Figure 3. The decay rate (a) and appearance (b) of strawberries packed in different corrugated cardboard boxes during storage at room temperature.

Moreover, the decay rate of strawberries was also highly influenced by the concentration of $\mathrm{NaClO}_{2}$ in the coating layer of coated boxes. Strawberries packed in $9 \mathrm{~g} / \mathrm{L} \mathrm{NaClO}$ corrugated boxes presented the lowest decay rate among all the groups during storage, while $6 \mathrm{~g} / \mathrm{L} \mathrm{NaClO}_{2}$ presented a rapidly increased decay rate from day 4. According to the release behavior given in Figure 2, the coated cardboard with a higher content of $\mathrm{NaClO}_{2}$ was able to release more $\mathrm{ClO}_{2}$ in a longer time period, which led to a sustainable antimicrobial effect.

\subsubsection{Weight Loss}

Postharvest fruit keeps losing weight due to transpiration, which will considerably affect its appearance, texture, taste and nutritional quality. Weight loss is particularly serious in strawberry due to its high water content and fragile surface. As shown in Figure 4, weight loss of control increased rapidly with time, which reached almost $20 \%$ at day 6 . However, strawberries packed in $3 \mathrm{~g} / \mathrm{L} \mathrm{NaClO}{ }_{2}$, $6 \mathrm{~g} / \mathrm{L} \mathrm{NaClO}$ and $9 \mathrm{~g} / \mathrm{L} \mathrm{NaClO}_{2}$ boxes showed significantly lower weight loss compared to that of control, and no significant difference was observed among these groups except for on day 3 . The results indicated that weight loss of strawberry was significantly reduced by the $\mathrm{ClO}_{2}$ treatment, but it was not denpendent on the $\mathrm{ClO}_{2}$ concentration within the concentration range used in this study. Similar effects of $\mathrm{ClO}_{2}$ releasing pad on the treated strawberries stored below $10^{\circ} \mathrm{C}$ have been reported by Wang et al. [16]. They attributed the reduced weight loss of strawberries to the closure of stomatal pore and reduction in the metabolism activities of fruits.

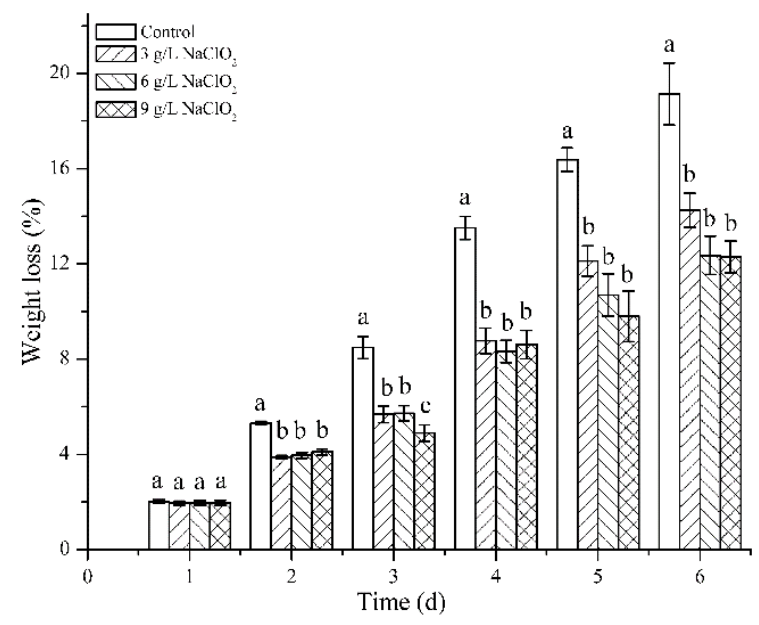

Figure 4. Weight loss of strawberries packed in different corrugated cardboard boxes during storage at room temperature. Means of differenct samples with different letters $(a, b, c)$ on the same day of storage were significantly different $(P>0.05)$. 


\subsubsection{Surface Color}

The surface color of strawberries not only reflects the freshness and maturity, but also indicates the changes of internal substances. During the storage of strawberry, loss of brightness with increasing time was visible and was evidenced by the significantly decreased value of $L^{*}$ as listed in Table 2 . However, strawberries packed in $9 \mathrm{~g} / \mathrm{L} \mathrm{NaClO}$ boxes showed significantly higher $L^{*}$ and $a^{*}$ values since day 2 in comparison with that of control, which indicated their better maintained brightness and red color, thus making them more preferred by the consumer. Arango et al. [26] observed the discoloration of strawberries after treatment with $\mathrm{ClO}_{2}$ due to the oxidative bleaching effect, but it depended on the concentration of $\mathrm{ClO}_{2}$ and exposure time. Therefore, the concentration of $\mathrm{ClO}_{2}$ released from the coated box in this study was not high enough to cause the bleaching of strawberries.

Table 2. Color parameters of strawberries packed in different corrugated cardboard boxes during storage at room temperature.

\begin{tabular}{|c|c|c|c|c|c|}
\hline \multirow{2}{*}{\multicolumn{2}{|c|}{ Color Parameter }} & \multicolumn{4}{|c|}{ Storage Time (d) } \\
\hline & & 0 & 2 & 4 & 6 \\
\hline \multirow{4}{*}{$L^{*}$} & Control & $31.84 \pm 3.98^{\mathrm{aA}}$ & $28.59 \pm 2.29^{\mathrm{bB}}$ & $26.87 \pm 1.78^{\mathrm{bB}}$ & $21.09 \pm 3.40^{\mathrm{abC}}$ \\
\hline & $3 \mathrm{~g} / \mathrm{L} \mathrm{NaClO} 2$ & $31.84 \pm 3.98^{\mathrm{aA}}$ & $29.13 \pm 1.84^{\mathrm{abB}}$ & $27.20 \pm 2.16^{\mathrm{abB}}$ & $20.62 \pm 2.04^{\mathrm{bC}}$ \\
\hline & $6 \mathrm{~g} / \mathrm{L} \mathrm{NaClO} 2$ & $31.84 \pm 3.98^{\mathrm{aA}}$ & $29.26 \pm 2.18^{\mathrm{abB}}$ & $28.75 \pm 1.45^{\mathrm{aB}}$ & $21.04 \pm 2.63^{\mathrm{abC}}$ \\
\hline & $9 \mathrm{~g} / \mathrm{L} \mathrm{NaClO} 2$ & $31.84 \pm 3.98^{\mathrm{aA}}$ & $30.29 \pm 2.11^{\mathrm{aAB}}$ & $28.98 \pm 1.77^{\mathrm{aB}}$ & $22.76 \pm 0.99^{\mathrm{aC}}$ \\
\hline \multirow{4}{*}{$a^{*}$} & Control & $37.94 \pm 1.27^{\mathrm{aA}}$ & $32.55 \pm 1.97^{\mathrm{bB}}$ & $31.41 \pm 2.18^{\mathrm{bB}}$ & $31.51 \pm 3.69^{\mathrm{cB}}$ \\
\hline & $3 \mathrm{~g} / \mathrm{L} \mathrm{NaClO} 2$ & $37.94 \pm 1.27^{\mathrm{aA}}$ & $34.49 \pm 1.72^{\mathrm{aB}}$ & $33.22 \pm 1.68^{\mathrm{aC}}$ & $35.08 \pm 1.59^{\mathrm{aB}}$ \\
\hline & $6 \mathrm{~g} / \mathrm{L} \mathrm{NaClO} 2$ & $37.94 \pm 1.27^{\mathrm{aA}}$ & $33.26 \pm 2.90^{\mathrm{abB}}$ & $33.85 \pm 1.96^{\mathrm{aB}}$ & $33.40 \pm 4.51^{\mathrm{bB}}$ \\
\hline & $9 \mathrm{~g} / \mathrm{L} \mathrm{NaClO} 2$ & $37.94 \pm 1.27^{\mathrm{aA}}$ & $34.32 \pm 2.10^{\mathrm{aB}}$ & $31.25 \pm 1.58^{\mathrm{bC}}$ & $33.24 \pm 1.09^{\mathrm{bB}}$ \\
\hline \multirow{4}{*}{$b^{*}$} & Control & $36.29 \pm 4.23^{\mathrm{aA}}$ & $22.43 \pm 1.74^{\mathrm{cB}}$ & $18.47 \pm 1.76^{\mathrm{cC}}$ & $17.63 \pm 1.44^{\mathrm{aC}}$ \\
\hline & $3 \mathrm{~g} / \mathrm{L} \mathrm{NaClO} 2$ & $36.29 \pm 4.23^{\mathrm{aA}}$ & $24.65 \pm 1.91^{\mathrm{aB}}$ & $20.55 \pm 1.73^{\mathrm{aB}}$ & $14.08 \pm 1.44^{\mathrm{cC}}$ \\
\hline & $6 \mathrm{~g} / \mathrm{L} \mathrm{NaClO} 2$ & $36.29 \pm 4.23^{\mathrm{aA}}$ & $22.43 \pm 1.85^{\mathrm{cB}}$ & $19.63 \pm 1.92^{\mathrm{bBC}}$ & $16.73 \pm 1.72^{\mathrm{bC}}$ \\
\hline & $9 \mathrm{~g} / \mathrm{L} \mathrm{NaClO}_{2}$ & $36.29 \pm 4.23^{\mathrm{aA}}$ & $23.07 \pm 1.74^{\mathrm{bB}}$ & $18.83 \pm 1.82^{\mathrm{cC}}$ & $16.35 \pm 1.83^{\mathrm{bC}}$ \\
\hline
\end{tabular}

For each color parameter, mean values in the same column with different lowercase superscript $(a, b, c)$ are significantly different $(P<0.05)$; mean values in the same row with different captial letter $(A, B, C)$ superscript are significantly different $(P<0.05)$.

\subsubsection{Firmness}

During storage, the firmness of all the groups decreased as shown in Figure 5a. However, control presented the lowest firmness among all the groups since day 2, which demonstrated that the firmness of strawberries packed in $6 \mathrm{~g} / \mathrm{L} \mathrm{NaClO}$, and $9 \mathrm{~g} / \mathrm{L} \mathrm{NaClO}$ was better maintained by $\mathrm{ClO}_{2}$ treatment. The delayed softening of fruit by $\mathrm{ClO}_{2}$ treatment has been widely reported [3], which was mainly related to the reduced metabolism and inhibited activities of enzymes.

\subsubsection{Content of AA, TA, and TSS}

AA, TA, and TSS are important nutrients, which are also involved in the postharvest activities of strawberries. AA helps to clean up free radicals in fruits, TA content is closely related to the flavour, while TSS are the substrates of metabolism activities [27]. As shown in Figure 5b-d, the strawberries packed in the coated box, particularly $9 \mathrm{~g} / \mathrm{L} \mathrm{NaClO}_{2}$, showed relatively higher content of AA, TA and TSS during storage. Therefore, it indicated that $\mathrm{ClO}_{2}$ treatment help keep the content of these nutrients in strawberries during storage, which might be attributed to the reduced consumption of these nutrients as the ripening process was slowed down. 

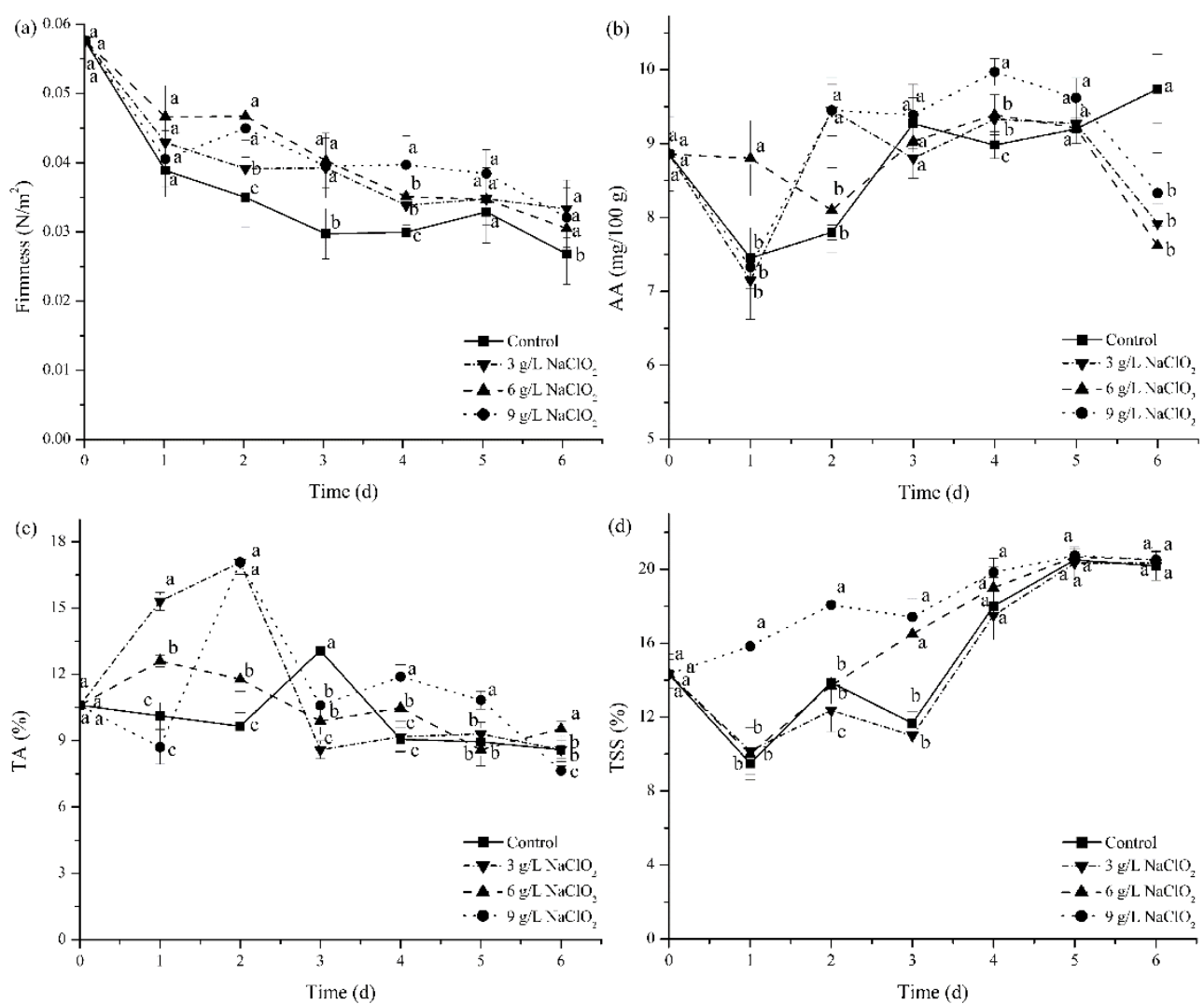

Figure 5. Firmness (a), AA content (b), TA content (c) and TSS content (d) of strawberries packed in different corrugated cardboard boxes during storage at room temperature. Means of different samples with different letters $(a, b, c)$ on the same day of storage were significantly different $(P>0.05)$.

\section{Conclusions}

In this study, $\mathrm{ClO}_{2}$ controlled-release corrugated boxes were successfully prepared by a two-layers coating of PVA- $\mathrm{NaClO}_{2}$-diatomite mixture and chitosan acetic acid solution. Results showed that in a high humidity environment, water vapor was able to swell chitosan and PVA layer to release $\mathrm{H}^{+}$, which react with $\mathrm{NaClO}_{2}$ to release gaseous $\mathrm{ClO}_{2}$, while diatomite was effective in stabilizing the release. With increasing $\mathrm{NaClO}_{2}$ concentrations in the coating, more $\mathrm{ClO}_{2}$ was released in an extended time period. When the coated corrugated box was used as the packaging of fresh strawberries, gaseous $\mathrm{ClO}_{2}$ was able to be released under the trigger of moisture and $\mathrm{CO}_{2}$ generated by the respiration and transpiration of strawberries. Therefore, inhibited decay, reduced weight loss, better-maintained surface color and nutrients content in strawberries packed in $9 \mathrm{~g} / \mathrm{L} \mathrm{NaClO}_{2}$ box were observed in comparison with those packed in control. Therefore, the well-designed coated corrugated box with the advantages of safety, effectiveness and feasibility, has great potential to be used as fresh-keeping packaging of fresh fruits and vegetables.

Author Contributions: Conceptualization, D.X. and Y.L.; Methodology, Y.L.; Writing-Original Draft Preparation, Y.L.; Writing-Review and Editing, D.X. and D.R.; Funding Acquisition, D.X. All authors have read and agreed to the published version of the manuscript.

Funding: This research was funded by the National Natural Science Foundation of China (31772028) and the Fundamental Research Funds for the Central Universities of China (XDJK2020B042).

Conflicts of Interest: The authors declare there is no conflict of interest. 


\section{References}

1. Arango, J.; Rubino, M.I.; Auras, R.; Rachford, A.A.; Bai, Z.; Grzesiak, A.L.; Kijchavengkul, T. In situ quantification of chlorine dioxide gas consumption by fresh produce using UV-visible spectroscopy. J. Food Eng. 2014, 131, 75-81. [CrossRef]

2. Benbettaieb, N.; Debeaufort, F.; Karbowiak, T. Bioactive edible films for food applications: mechanisms of antimicrobial and antioxidant activity. Crit. Rev. Food Sci. Nutr. 2019, 59, 3431-3455. [CrossRef] [PubMed]

3. Praeger, U.; Herppich, W.B.; Hassenberg, K. Aqueous chlorine dioxide treatment of horticultural produce: Effects on microbial safety and produce quality-A review. Crit. Rev. Food Sci. Nutr. 2018, 58, 318-333. [CrossRef] [PubMed]

4. Han, Y.; Floros, J.D.; Linton, R.H.; Nielsen, S.S.; Nelson, P.E. Response surface modeling for the inactivation of Escherichia coli O157:H7 on green peppers (Capsicum annuum L.) by chlorine dioxide gas treatments. J. Food Prot. 2010, 67, 1188-1193. [CrossRef] [PubMed]

5. Golden, C.E.; Berrang, M.E.; Kerr, W.L.; Harrison, M.A. Slow-release chlorine dioxide gas treatment as a means to reduce Salmonella contamination on spices. Innov. Food Sci. Emerg. Technol. 2019, 52, $256-261$. [CrossRef]

6. Eryilmaz, M.; Kaskatepe, B.; Kiymaci, M.E.; Erol, H.B.; Simsek, D.; Gumustas, A. In vitro antimicrobial activity of three new generation disinfectants. Trop. J. Pharm. Res. 2016, 15, 2191-2195. [CrossRef]

7. Lee, H.; Ryu, J.H.; Kim, H. Antimicrobial activity of gaseous chlorine dioxide against Aspergillus flavus on green coffee beans. Food Microbiol. 2020, 86, 103308. [CrossRef]

8. Yan, R.; Chen, Q.; Fu, M. Chlorine dioxide generation method and it's action mechanism for removing harmful substances and maintaining quality attributes of agricultural products. Food Bioprocess Technol. 2019, $12,1110-1122$.

9. Qin, G.; Wu, B.; Peng, X.; Wang, J.; Li, Q.; Jing, J.; Ha, Y. Effects of chlorine dioxide treatment on respiration rate and ethylene synthesis of postharvest tomato fruit. Postharvest Biol. Technol. 2014, 93, 9-14.

10. Chumyam, A.; Shank, L.; Uthaibutra, J.; Saengnil, K. Effects of chlorine dioxide on mitochondrial energy levels and redox status of 'Daw' longan pericarp during storage. Postharvest Biol. Technol. 2016, 116, 26-35. [CrossRef]

11. Sun, X.; Zhou, B.; Luo, Y.; Ference, C.; Baldwin, E.; Harrison, K.; Bai, J. Effect of controlled-release chlorine dioxide on the quality and safety of cherry/grape tomatoes. Food Control 2017, 82, 26-30. [CrossRef]

12. Zhang, B.; Huang, C.; Zhang, L.; Wang, J.; Huang, X.; Zhao, Y.; Liu, Y.; Li, C. Application of chlorine dioxide microcapsule sustained-release antibacterial films for preservation of mangos. J. Food Sci. Technol.-Mys. 2019, 56, 1095-1103. [CrossRef] [PubMed]

13. Fu, M.R.; Zhang, X.M.; Jin, T.; Li, B.Q.; Zhang, Z.Q.; Tian, S.P. Inhibitory of grey mold on green pepper and winter jujube by chlorine dioxide $\left(\mathrm{ClO}_{2}\right)$ fumigation and its mechanisms. LWT-Food Sci. Technol. 2019, 100, 335-340. [CrossRef]

14. Yang, H.; Zheng, J.; Huang, C.; Zhao, X.; Chen, H.; Sun, Z. Effects of combined aqueous chlorine dioxide and chitosan coatings on microbial growth and quality maintenance of fresh-cut bamboo shoots (Phyllostachys praecox f. prevernalis.) during storage. Food Bioprocess Technol. 2015, 8, 1011-1019. [CrossRef]

15. Wei, J.; Chen, Y.; Tiemur, A.; Wang, J.; Wu, B. Degradation of pesticide residues by gaseous chlorine dioxide on table grapes. Postharvest Biol. Technol. 2018, 137, 142-148. [CrossRef]

16. Wang, Z.; Narciso, J.; Biotteau, A.; Plotto, A.; Baldwin, E.; Bai, J. Improving storability of fresh strawberries with controlled release chlorine dioxide in perforated clamshell packaging. Food Bioprocess Technol. 2014, 7 , 3516-3524. [CrossRef]

17. Sun, X.; Bai, J.; Ference, C.; Wang, Z.; Zhang, Y.; Narciso, J.; Zhou, K. Antimicrobial activity of controlled-release chlorine dioxide gas on fresh blueberries. J. Food Prot. 2014, 77, 1127-1132. [CrossRef]

18. Chen, M.; Chen, X.; Yam, K. Encapsulation complex of chlorine dioxide in alpha-cyclodextrin: Structure characterization and release property. Food Control 2020, 107, 106783. [CrossRef]

19. Saade, C.; Annous, B.A.; Gualtieri, A.J.; Schaich, K.M.; Liu, L.; Yam, K.L. System feasibility: Designing a chlorine dioxide self-generating package label to improve fresh produce safety part II: Solution casting approach. Innov. Food. Sci. Emerg. Technol. 2018, 47, 110-119. [CrossRef] 
20. Bai, Z.; Cristancho, D.E.; Rachford, A.A.; Reder, A.L.; Williamson, A.; Grzesiak, A.L. Controlled release of antimicrobial $\mathrm{ClO}_{2}$ gas from a two-layer polymeric film system. J. Agric. Food Chem. 2016, 64, 8647-8652. [CrossRef]

21. Li, S.; Xiao, S.; Luo, Y. Effect of preservative paper coating on $\mathrm{NaClO}_{2}$ retention rate and $\mathrm{ClO}_{2}$ release rule. Packag. Eng. 2017, 38, 31-35.

22. Cao, J.; Jiang, W.; Zhao, Y. Physiological and Biochemical Experiment Guidance of Postharvest Fruits and Vegetables, 1st ed.; China Light Industry Book Press: China, Beijing, 2007; pp. 37-39.

23. Aghaeifard, F.; Babalar, M.; Fallahi, E.; Ahmadi, A. Influence of humic acid and salicylic acid on yield, fruit quality, and leaf mineral elements of strawberry (fragaria $\times$ ananassa duch.) cv. camarosa. J. Plant Nutr. 2015, 39, 1821-1829. [CrossRef]

24. Fadiji, T.; Berry, T.M.; Coetzee, C.J.; Opara, U.L. Mechanical design and performance testing of corrugated paperboard packaging for the postharvest handling of horticultural produce. Biosys. Eng. 2018, 171, $220-244$. [CrossRef]

25. Sun, X.; Baldwin, E.; Bai, J. Applications of gaseous chlorine dioxide on postharvest handling and storage of fruits and vegetables-A review. Food Control 2019, 95, 18-26. [CrossRef]

26. Arango, J.; Rubino, M.; Auras, R.; Gillett, J.; Schilder, A. Evaluation of chlorine dioxide as an antimicrobial against Botrytis cinerea in California strawberries. Food Packaging Shelf 2016, 9, 45-54. [CrossRef]

27. Nguyen, V.T.B.; Nguyen, D.H.H.; Nguyen, H.V.H. Combination effects of calcium chloride and nano-chitosan on the postharvest quality of strawberry (Fragaria $\times$ ananassa Duch.). Postharvest Biol. Technol. 2020, 162, 111103. [CrossRef]

(C) 2020 by the authors. Licensee MDPI, Basel, Switzerland. This article is an open access article distributed under the terms and conditions of the Creative Commons Attribution (CC BY) license (http://creativecommons.org/licenses/by/4.0/). 